\title{
Vaccinia Virus
}

National Cancer Institute

\section{Source}

National Cancer Institute. Vaccinia Virus. NCI Thesaurus. Code C14281.

DNA viruses used in several biotechnology applications, including expression vector systems. 